\title{
Effects of Protein and Energy on Dietary Selection and Protein Utilization in Rats with Ventromedial Hypothalamic Lesions
}

\author{
Fujiko SHIzUKA, Kyoichi KISHI, and Goro INOUE ${ }^{1}$ \\ Department of Nutrition, School of Medicine, \\ The University of Tokushima, \\ 3-Kuramotocho, Tokushima 770, Japan
}

(Received November 29, 1982)

Summary The effect of bilateral destruction of the ventromedial hypothalamus (VMH) on protein and energy intakes was examined in relation to protein utilization. In Experiment 1, rats with $\mathrm{VMH}$ lesions were allowed to select protein (either casein or wheat gluten) and energy from two diets containing $70 \%$ and $5 \%$ protein, respectively. In Experiment 2, they were restricted to 0,100 and $200 \mathrm{mg} \mathrm{N} /$ day of protein and given free access to protein-free diet. In Experiment 3, they were restricted to 2 and $5 \mathrm{~g} /$ day of protein-free diet but given $92 \%$ protein diet ad libitum.

Self-selecting rats with VMH lesions consumed about $100 \mathrm{kcal} /$ day regardless of the protein source, in contrast to sham-operated controls which consumed $75 \mathrm{kcal} /$ day. They showed increased non-protein energy intake with constant protein consumption resulting in normal protein retention with increased body fat. When protein intake was restricted to $200 \mathrm{mg} \mathrm{N} /$ day, energy intake was reduced in animals given diet containing wheat gluten more than in those given diet containing casein, resulting in lower protein utilization. Therefore, food intake depended upon the amount of dietary protein. Rats with $\mathrm{VMH}$ lesions showed an exaggerated response to the ratio of protein to energy in the diet and consumed more energy from balanced diet but showed more reduction in food intake than controls in response to diet with an inappropriate ratio of protein to energy.

The present study confirmed that the $\mathrm{VMH}$ was related to regulation of energy intake but not protein intake. It is suggested that protein intake is regulated in relation to maintenance of body protein in rats with $\mathrm{VMH}$ lesions as well as in normal rats.

Key Words self-selection, protein restriction, energy restriction, protein utilization, protein intake regulation, VMH lesion

1 志塚ふじ子, 岸 恭一, 井上五郎 
Bilateral destruction of the ventromedial hypothalamus (VMH) produces the characteristic symptoms of hyperphagia, hyper-reactivity to palatability of the diet, and hormonal and metabolic alterations associated with enhanced accumulation of body fat (for recent review see(1)). From the symptom of hyperphagia, this locus has been recognized as the "satiety center" and the hypothesis of a dual center of food intake has been established (2).

It is well known that both the quality and quantity of protein in the diet affect food intake. Food intake of rats with VMH lesions as well as of intact rats is depressed in response to a diet with excess of a single amino acid(3), with an imbalance of amino acids $(3,4)$, and with a high protein content $(3,5)$. Moreover, Rozin (6), Musten et al.(7), and Kishi et al. (8) suggested that the regulations of protein intake and energy intake are different. Anderson et al. (9) concluded from a study on self-selection of diet that regulation of protein intake was normal in both hypothalamic hyperphagic and obese Zucker rats. The mechanism of regulation of protein and amino acid intakes is still unknown, but although direct evidence is still lacking, the VMH is not supposed to be involved.

From the nutritional point of view, dietary protein has two functions, as a constituent of body proteins and as energy source. When the diet has a high protein content, more protein is used as an energy source and consequently less for body protein synthesis. On the other hand, a protein sparing effect (10) is observed with excess of energy-yielding nutrients. Protein utilization, therefore, is affected not only by the ingested protein per se but also by the amount of ingested energy. Because of this reciprocal metabolic relationship, the interaction of the protein and energy contents of the diet may influence the feeding behavior. In fact, food intake was depressed in rats fed on a very low or high protein diet $(11,12)$.

The present study was undertaken to explore the possible relationship between self-selection of dietary protein and its subsequent utilization in rats with VMH lesions. In further studies on the feeding behavior of rats with VMH lesions, we also studied dietary selection of non-protein energy in response to restricted protein intake and vice versa.

\section{MATERIALS AND METHODS}

Male Wistar strain rats weighing about $230 \mathrm{~g}$ were obtained commercially. They were kept in individual wire-mesh cages in a room maintained at $23 \pm 1^{\circ} \mathrm{C}$ with a 12-hr light-dark cycle. After feeding on a control diet or self-selection diets (as described later), animals weighing about $250 \mathrm{~g}$ were divided into groups with VMH lesions and with sham operations (control) and were given test diets for four weeks. Three series of dietary treatment were used: self-selection of both protein and energy (Experiment 1), protein restriction with energy available ad libitum (Experiment 2) and energy 'restriction with protein available ad libitum (Experiment 3).

The control diet contained the following components $(\%)$ : casein $(20.0)$, $\alpha$ cornstarch (44.7), sucrose (22.3), corn oil (5.0), mineral mixture ${ }^{1}$ (5.0), vitamin 
mixture $^{2}(1.0)$ and cellulose powder (2.0). Experimental diets varying in protein content were made by substituting the protein source for an equal weight of carbohydrate consisting of cornstarch and sucrose (2:1). All diets were prepared with adequate amounts of water to make them easy to eat. Tap water was freely available at all times.

The intake of dry matter and body weight were recorded daily. At the end of the experimental period, blood was withdrawn from the inferior vena cava and the liver was removed. The rest of the carcass was then frozen for analyses of water, fat and protein. The frozen carcass was minced and dried in an oven at $95^{\circ} \mathrm{C}$ for $48 \mathrm{hr}$. The weight of water was calculated as the difference between the wet and dry weights. Fat in the dried carcass was determined by ether extraction in a Goldfisch apparatus (LABCONCO Corporation, Kansas City, Mo., U.S.A.) for $4 \mathrm{hr}$. The nitrogen contents of the diet and carcass were analyzed by the Kjeldahl method, and the protein content was calculated as $\mathrm{N} \times 6.25$. The protein sources used in experiments were casein and wheat gluten, whose protein contents $(\mathrm{N} \times 6.25)$ were 85.72 and $80.13 \%$, respectively. Energy contents of diets were calculated using energy conversion factors of $3.42,3.87,8.84$ and $4.0 \mathrm{kcal} / \mathrm{g}$ for cornstarch, sucrose, corn oil and protein, respectively (13).

Surgery and histology. Rats were anesthetized by intraperitoneal injection of sodium pentobarbital $(42.5 \mathrm{mg} / \mathrm{kg})$ and were placed in a rigid stereotaxic apparatus in which the upper incisor bar was $3 \mathrm{~mm}$ under the horizontal plane of the ear bar. A nichrome wire needle of $0.4 \mathrm{~mm}$ in diameter, insulated except for $0.5 \mathrm{~mm}$ from the tip, was used to introduce lesions into the ventromedial hypothalamus. The coordinates used were $6.0 \mathrm{~mm}$ anterior to the ear bar, $\pm 0.7 \mathrm{~mm}$ lateral to the midline suture and $0.8 \mathrm{~mm}$ dorsal to the sphenoid bone. Bilateral electrolytic lesions were produced by passing a direct current of $2 \mathrm{~mA}$ through the electrode tip for 15 sec. Sham control animals underwent the same treatment but without a current. Immediately after operation, rats were injected subcutaneously at the site of the wound with 5,000 units of penicillin and were returned to their cages.

After the experiment, rats with VMH lesions were anesthetized with ether and the brain was perfused with isotonic saline and then $10 \%$ formalin solution. The brain was removed, fixed in $10 \%$ formalin and embedded in gelatin. Histological analysis was performed by light microscopic examination of $50 \mu$-coronal sections

1 Obtained from Oriental Yeast Co., Ltd., Tokyo. The mineral mixture contained (\%): $\mathrm{CaHPO}_{4} \cdot 2 \mathrm{H}_{2} \mathrm{O}, 14.56 ; \mathrm{KH}_{2} \mathrm{PO}_{4}, 25.72 ; \mathrm{NaH}_{2} \mathrm{PO}_{4}, 9.35 ; \mathrm{NaCl}$, 4.66; Ca-lactate, 35.09; Fecitrate, 3.18; $\mathrm{MgSO}_{4}, 7.17 ; \mathrm{ZnCO}_{3}, 0.11 ; \mathrm{MnSO}_{4} \cdot 4-6 \mathrm{H}_{2} \mathrm{O}, 0.12 ; \mathrm{CuSO}_{4} \cdot 5 \mathrm{H}_{2} \mathrm{O}, 0.03 ; \mathrm{KI}$, 0.01 .

2 Obtained from Oriental Yeast Co., Ltd., Tokyo. Composition expressed in units or milligrams per $100 \mathrm{~g}$ of vitamin mixture: thiamine- $\mathrm{HCl}, 120$; riboflavin, 400; pyridoxine$\mathrm{HCl}, 80$; vitamin $\mathrm{B}_{12}, 0.05$; ascorbic acid, 3,000; D-biotin, 2; folic acid, 20; calcium pantothenate, 500; $p$-amino benzoic acid, 500; niacin, 600; inositol, 600; choline chloride, 20,000; retinyl acetate (IU), 50,000; ergocalciferol (IU), 10,000; tocopheryl acetate, 500; menadione, 520 .

Vol. 29, No. 2, 1983 
cut on a freezing microtome and stained with cresyl violet. The atlas of De Groot (14) was used in locating lesions. Rats with incomplete or asymmetrical lesions were omitted from effective numbers.

Experiment 1. Dietary self-selection of protein and energy by rats with VMH lesions and control animals was performed. Rats were allowed to select either diet containing $5 \%$ or $70 \%$ protein (Self-selection groups), after full adaptation to this regimen before surgery. For examination of the influence of protein quality on protein intake, casein and wheat gluten were used as protein sources. The total energy intakes of rats in self-selection groups were compared with those of fixedratio diet groups, given control diet containing $20 \%$ casein.

Experiment 2. Protein restriction ( $200 \mathrm{mg} \mathrm{N} /$ day) was performed by restriction of the intake of $40 \%$ casein or wheat gluten diet to $3.65 \mathrm{~g}$ or $3.90 \mathrm{~g} /$ day, respectively, with free access to protein-free diet (non-protein energy source). More severe protein-restriction was done by restricting the intake of $40 \%$ casein diet to $1.82 \mathrm{~g}$ $(100 \mathrm{mg} \mathrm{N}) /$ day or $0 \mathrm{~g}(0 \mathrm{mg} \mathrm{N}) /$ day with protein-free diet ad libitum.

Experiment 3. Non-protein energy restriction was performed by restricting the protein-free diet to $5 \mathrm{~g}(17.7 \mathrm{kcal}) /$ day with protein diet containing casein or wheat gluten ad libitum, or to $2 \mathrm{~g}(7.1 \mathrm{kcal}) /$ day with free access to $92 \%$ casein diet. Protein diet consisted of $5 \%$ mineral mixture, $1 \%$ vitamin mixture, $2 \%$ cellulose powder and $92 \%$ casein or wheat gluten.

\section{RESULTS}

\section{Experiment 1}

Rats with VMH lesions ate more food than sham-operated control rats from the day of surgery. Their average energy intakes in four weeks are shown in Table 1. Self-selecting rats with VMH lesions consumed nearly $100 \mathrm{kcal} /$ day, whereas controls consumed about $75 \mathrm{kcal} /$ day. These values were comparable with those in fixed-ratio groups, indicating that the feeding method had no influence on the total energy intake. In contrast with results on the total energy intake, in self-selecting groups, the protein intakes of rats with $\mathrm{VMH}$ lesions and controls were similar, being about $30 \mathrm{kcal} / \mathrm{day}$ in both casein and wheat gluten groups. Hyperphagia induced by lesions was due to increased intake of non-protein energy, as shown in Table 1. A similar tendency was observed when total and protein energy intakes were expressed per $100 \mathrm{~g}$ body weight.

Due to high energy intake, rats with $\mathrm{VMH}$ lesions gained more weight than controls: At the end of the experiment, the body weight of rats with lesions was about $460 \mathrm{~g}$, which was about $50 \mathrm{~g}$ more than that of controls (Table 2). The "Lee index" (15) was used to assess the degree of obesity. Values correlated well with the final body weight, because the body length was similar in all groups. Carcass analyses showed that in rats with VMH lesions, fat amounted to more than $30 \%$ of the carcass weight, whereas in controls it amounted to about $20 \%$ (Table 3). An inverse relation was observed between the percentage contents of fat and protein in 


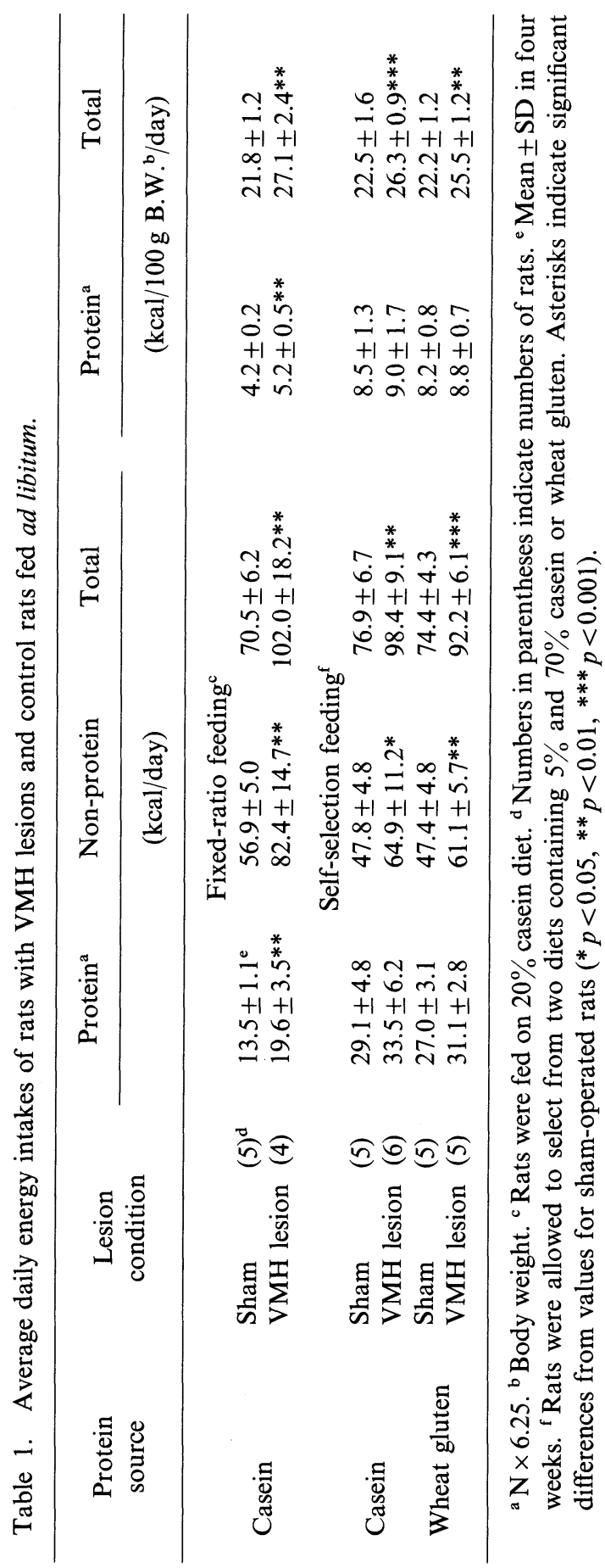


Table 2. Body weight and Lee index of rats fed ad libitum.

\begin{tabular}{|c|c|c|c|c|c|}
\hline $\begin{array}{l}\text { Protein } \\
\text { source }\end{array}$ & $\begin{array}{l}\text { Lesion } \\
\text { condition }\end{array}$ & & $\begin{array}{l}\text { Body } \\
\text { weight } \\
\text { (g) }\end{array}$ & $\begin{array}{l}\text { Nose-anal } \\
\text { length } \\
(\mathrm{cm})\end{array}$ & Lee index ${ }^{a}$ \\
\hline Casein & $\begin{array}{l}\text { Sham } \\
\text { VMH lesion }\end{array}$ & $\begin{array}{l}\text { Fixed- } \\
(5)^{c} \\
(4)\end{array}$ & $\begin{array}{l}\text { ratio feeding } \\
389 \pm 16^{\mathrm{d}} \\
467 \pm 51^{*}\end{array}$ & $\begin{array}{l}23.0 \pm 0.2 \\
23.0 \pm 0.5\end{array}$ & $\begin{array}{l}318 \pm 3 \\
337 \pm 7 * * *\end{array}$ \\
\hline $\begin{array}{l}\text { Casein } \\
\text { Wheat gluten }\end{array}$ & $\begin{array}{l}\text { Sham } \\
\text { VMH lesion } \\
\text { Sham } \\
\text { VMH lesion }\end{array}$ & $\begin{array}{l}\text { Self-sel } \\
(5) \\
(6) \\
(5) \\
(5)\end{array}$ & $\begin{array}{l}\text { ction feeding } \\
415 \pm 16 \\
467 \pm 31^{\text {e }} \\
397 \pm 15 \\
446 \pm 20^{* *}\end{array}$ & $\begin{array}{l}23.4 \pm 0.3 \\
23.2 \pm 0.6 \\
22.9 \pm 0.3 \\
23.1 \pm 0.4\end{array}$ & $\begin{array}{l}319 \pm 3 \\
334 \pm 6 * * * \\
321 \pm 7 \\
332 \pm 8\end{array}$ \\
\hline $\begin{array}{l}{ }^{\mathrm{a}} \text { Lee index }= \\
{ }^{\mathrm{c}} \text { Numbers in } \\
\text { select from tw } \\
\text { significant di } \\
{ }^{* * *} p<0.001 \text { ) }\end{array}$ & $\begin{array}{l}\sqrt[3]{\text { Body weigh }} \\
\text { Nose-anal leng } \\
\text { parentheses indi } \\
\text { o diets containi } \\
\text { ferences from }\end{array}$ & $\begin{array}{l}\text { ht }(\mathrm{g}) \\
\text { gth }(\mathrm{cm}) \\
\text { licate nur } \\
\text { ing } 5 \% \text { a }\end{array}$ & $\begin{array}{l}1,000 .{ }^{b} \text { Rats } \\
70 \% \text { casein or } \\
7{ }^{d} \mathrm{M} \\
\text { sham-opera }\end{array}$ & $\begin{array}{l}\text { were fed on } \\
\text { lean } \pm \mathrm{SD} .{ }^{\mathrm{e}} \mathrm{R} \\
\text { wheat gluten } \\
\text { ted rats }\left(^{*} p\right.\end{array}$ & $\begin{array}{l}20 \% \text { casein diet. } \\
\text { ats were allowed to } \\
\text { Asterisks indicate } \\
<0.05, * * p<0.01 \text {, }\end{array}$ \\
\hline
\end{tabular}

the carcass. The absolute contents of protein and water, however, were almost the same in all groups, being about $80 \mathrm{~g}$ and $220 \mathrm{~g}$, respectively. In contrast to their lean body mass, animals with lesions had nearly twice as much fat as sham-operated controls. Thus, rats with lesions developed characteristic obesity, but had a normal body protein content.

Results on utilization of dietary protein, determined by carcass nitrogen analysis, are given in Table 4. In groups with fixed-ratio diet, the net protein utilization (NPU) (16) of casein was 43.5 for sham-operated rats consuming $15 \mathrm{~g}$ nitrogen, and 29.0 for rats with lesions consuming $22 \mathrm{~g}$ of nitrogen in four weeks. On the other hand, both rats with lesions and controls in self-selection groups consumed more than $30 \mathrm{~g}$ of nitrogen in four weeks, resulting in lower NPUs. The NPU of wheat gluten was not significantly lower than that of casein in either rats with lesions or controls, values being 16 vs 18 and 20 vs 23, respectively. The NPU decreased with increase in nitrogen intake, but did not differ in rats with lesions and controls at similar levels of nitrogen intake (Fig. 1). Despite the difference of the NPU, the net dietary protein calories percent (NDpCals \%) (17) of rats with VMH lesions were similar, being 5.5-6.1\%, irrespective of the feeding method and protein source (Table 4). Namely, the dietary protein retained as body protein was not influenced by protein consumption. In all groups with lesions more energy was consumed from the non-protein energy source, the NDpCals $\%$ being significantly $(p<0.01)$ lower than those of the respective control groups. 
PROTEIN INTAKE IN VMH RATS

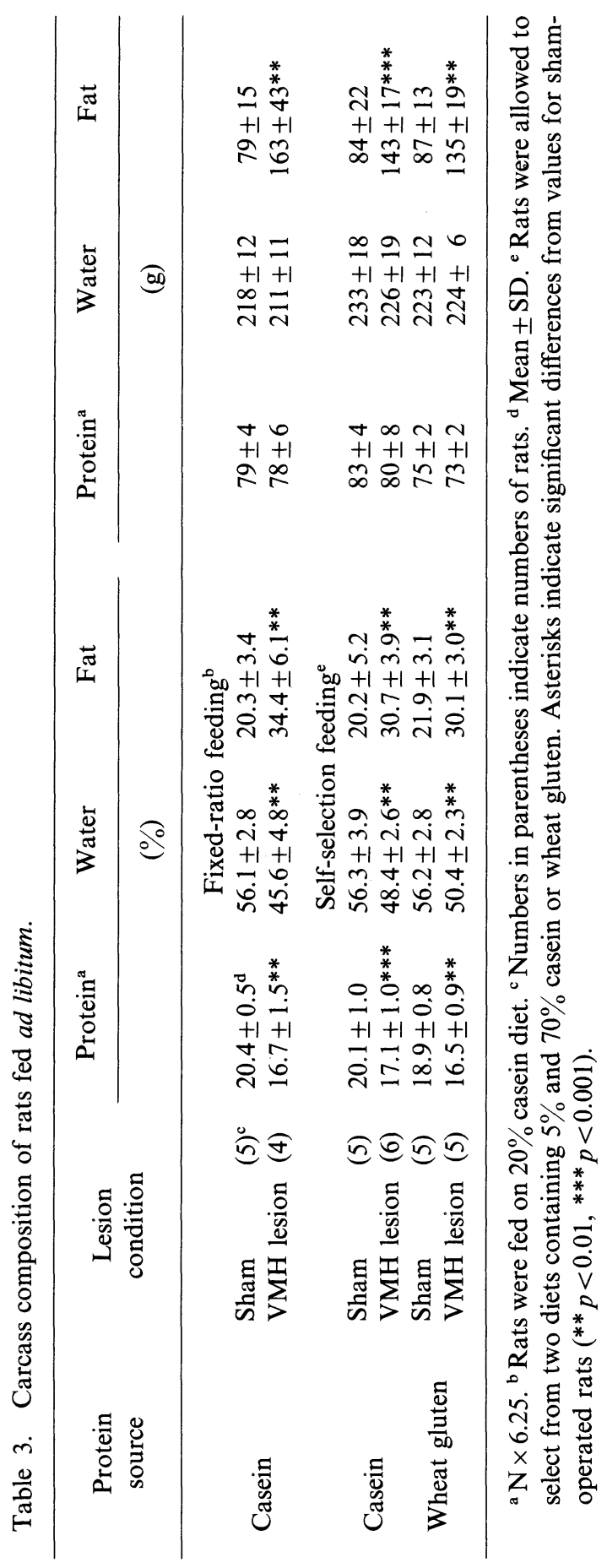

Vol. 29, No. 2, 1983 
Table 4. Protein utilization and net dietary protein calories per cent (NDpCals \%) in rats fed ad libitum.

\begin{tabular}{|c|c|c|c|c|c|c|}
\hline $\begin{array}{l}\text { Protein } \\
\text { source }\end{array}$ & $\begin{array}{l}\text { Lesion } \\
\text { condition }\end{array}$ & & $\begin{array}{l}\mathrm{N} \text { intake } \\
\text { (g/28 days) }\end{array}$ & $\mathrm{NPU}^{\mathrm{a}}$ & $\begin{array}{c}\text { Protein } \\
\text { Cals } \% \\
(\%)\end{array}$ & $\begin{array}{c}\text { NDpCals \% } \\
(\%)\end{array}$ \\
\hline \multicolumn{7}{|c|}{ Fixed ratio feeding ${ }^{b}$} \\
\hline Casein & $\begin{array}{l}\text { Sham } \\
\text { VMH lesion }\end{array}$ & $\begin{array}{l}(5)^{\mathrm{c}} \\
(4)\end{array}$ & $\begin{array}{l}15.2 \pm 1.3^{\mathrm{d}} \\
22.0 \pm 3.9^{* *}\end{array}$ & $\begin{array}{l}43.5 \pm 3.3 \\
29.0 \pm 5.2^{* *}\end{array}$ & 19.2 & $\begin{array}{l}8.4 \pm 0.6 \\
5.6 \pm 1.0^{* *}\end{array}$ \\
\hline \multicolumn{7}{|c|}{ Self-selection feeding ${ }^{\mathrm{e}}$} \\
\hline \multirow{2}{*}{ Casein } & Sham & (5) & $32.5 \pm 5.4$ & $22.5 \pm 3.3$ & $38.0 \pm 4.3$ & $8.5 \pm 1.0$ \\
\hline & VMH lesion & (6) & $37.5 \pm 6.9$ & $18.3 \pm 5.1$ & $34.7 \pm 7.2$ & $6.1 \pm 0.9 * *$ \\
\hline \multirow{2}{*}{ Wheat gluten } & Sham & (5) & $30.2 \pm 3.5$ & $19.5 \pm 2.0$ & $36.4 \pm 4.2$ & $7.1 \pm 0.7$ \\
\hline & VMH lesion & (5) & $34.8 \pm 3.1$ & $16.1 \pm 1.9^{*}$ & $34.0 \pm 3.1$ & $5.5 \pm 0.6^{* *}$ \\
\hline
\end{tabular}

${ }^{\mathrm{a}}$ Net protein utilization calculated from carcass $\mathrm{N}$ analysis. ${ }^{\mathrm{b}}$ Rats were fed on $20 \%$ casein diet. ${ }^{\mathrm{c}}$ Numbers in parentheses indicate numbers of rats. ${ }^{\mathrm{d}} \mathrm{Mean} \pm \mathrm{SD}$. ${ }^{\mathrm{e}}$ Rats were allowed to select from two diets containing $5 \%$ and $70 \%$ casein or wheat gluten. Asterisks indicate significant differences from values for sham-operated rats $\left({ }^{*} p<0.05\right.$, ** $p<0.01)$.
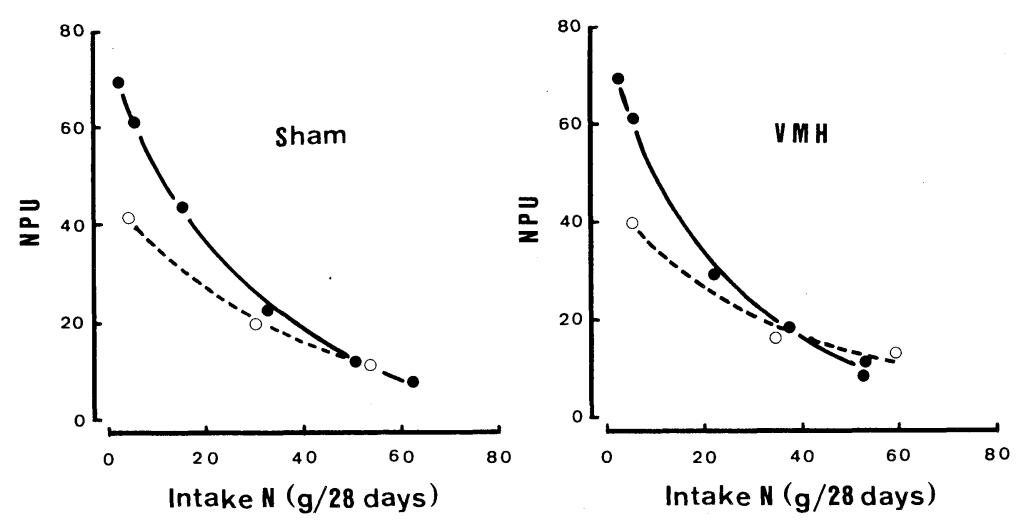

Fig. 1. Correlation between $\mathrm{N}$ intake and net protein utilization.(NPU) of rats with VMH lesions and sham-operated rats on three dietary regimens (Experiments 1-3) with casein (- - ) and wheat gluten (-- $\mathrm{O}_{--}$). Points are means for 4-6 rats and curves were drawn by inspection.

\section{Experiment 2}

Average energy consumptions in four weeks are shown in Fig. 2. Hyperphagia was not observed in rats with VMH lesions with restricted protein intake. Rats with lesions and control rats on casein diet consumed about 70 and $60 \mathrm{kcal} / \mathrm{day}$ at 200 and $100 \mathrm{mgN} /$ day, respectively, and these values did not differ significantly 
A. Energy intake

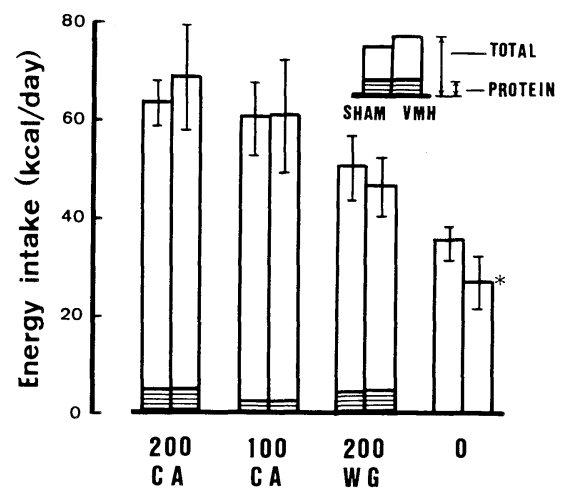

B. Body weight gain

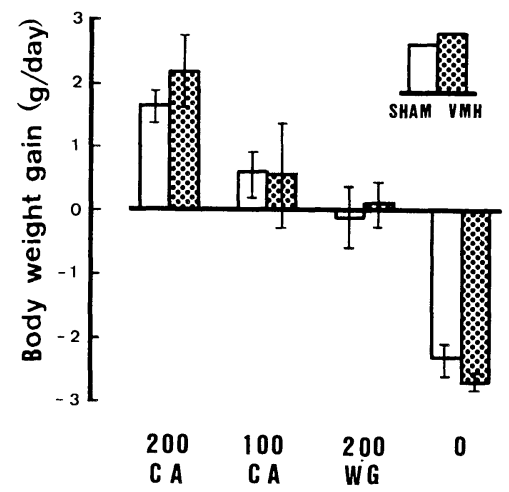

Fig. 2. Total and protein energy intakes, and body weight gains of protein-restricted rats in Experiment 2. $200 \mathrm{CA}, 100 \mathrm{CA}, 200 \mathrm{WG}$ and 0 represent nitrogen intakes from casein (CA) or wheat gluten (WG) in $\mathrm{mg} \mathrm{N} /$ day. Values are means $\pm \mathrm{SD}$ for 4-5 rats. The asterisk indicates a significant different from the value for shamoperated controls $\left({ }^{*} p<0.05\right)$.

A. Energy intake

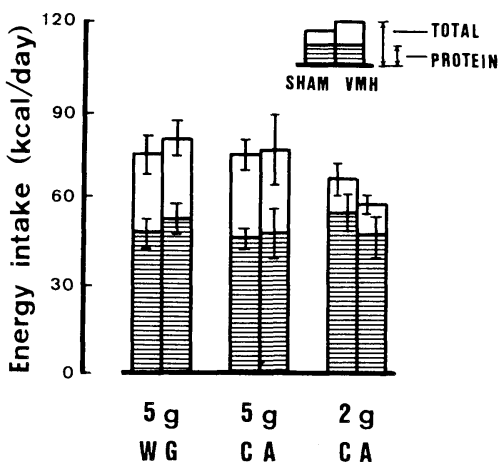

B. Body weight gain

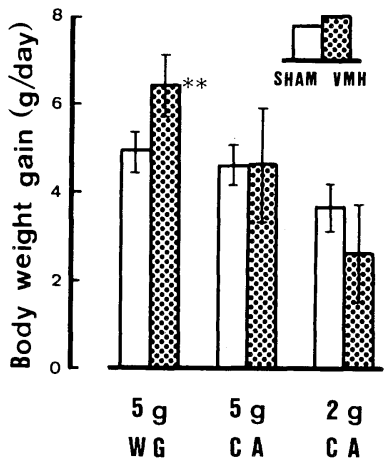

Fig. 3. Total and protein energy intakes, and body weight gains of energy-restricted rats in Experiment 3. Consumption of protein-free diet was restricted to $5 \mathrm{~g}$ /day with free access to $92 \%$ wheat diet for the $5 \mathrm{~g} \mathrm{WG}$ group, and was restricted to $5 \mathrm{~g}$ /day and $2 \mathrm{~g}$ /day with free access to $92 \%$ casein diet for the $5 \mathrm{~g} \mathrm{CA}$ and $2 \mathrm{~g} \mathrm{CA}$ groups, respectively. Values are means $\pm \mathrm{SD}$ for $4-5$ rats. Asterisks indicate a significant difference from the value for sham-operated controls $\left({ }^{* *} p<0.01\right)$.

$(p>0.05)$. Consequently, protein-energy from casein accounted for 8 and $4 \%$ of the total energy consumption of the $200 \mathrm{mg} \mathrm{N}$ and $100 \mathrm{mg} \mathrm{N}$ groups, respectively. Rats with lesions and controls restricted to $200 \mathrm{mg} \mathrm{N} /$ day of wheat gluten both consumed $50 \mathrm{kcal} /$ day, which was significantly $(p<0.01)$ lower than the energy consumed by rats fed casein at the same $\mathrm{N}$ level. The NPU of wheat gluten was 40 while that of 
casein was 60 when the rats consumed $5.6 \mathrm{~g}$ in 28 days (Fig. 1). On the other hand, rats with lesions fed on protein-free diet $(0 \mathrm{mg} \mathrm{N} /$ day $)$ consumed $27 \mathrm{kcal} /$ day, which was significantly $(p<0.05)$ less than the consumption of $36 \mathrm{kcal} /$ day by controls (Fig. 2) and was one-third of the total energy consumed by controls in Experiment 1.

Results on average body weight gain are shown in Fig. 2. Changes in energy intake were clearly reflected in body weight gain, which was highest in the casein group ( $200 \mathrm{mg} \mathrm{N} /$ day) and lowest in the protein-free diet group. Destruction of the VMH had little effect on the body weight gain of rats on restricted protein intake.

\section{Experiment 3}

In all rats food consumption was reduced in the initial stage of the feeding period, but increased toward the end of the first week to a fairly constant level. Figure 3 shows the average energy intakes in four weeks. Restriction of protein-free $\operatorname{diet}(5 \mathrm{~g} /$ day) had little affect on the total energy consumption and hyperphagia was not seen in rats with VMH lesions. The rats consumed $74-80 \mathrm{kcal} /$ day, like nonrestricted controls in Experiment 1. At a high protein intake (50-60 g of nitrogen in 28 days) caused by energy restriction, the NPUs of both casein and wheat gluten were similarly low (Fig. 1). On restriction of protein-free diet to $2 \mathrm{~g} /$ day, total energy intake was depressed more in rats with lesions than in controls (57 vs $66 \mathrm{kcal} /$ day). In contrast to controls, rats with lesions restricted to $2 \mathrm{~g}$ /day consumed significantly $(p<0.05)$ less total energy than rats restricted to $5 \mathrm{~g} /$ day. The rats restricted to $2 \mathrm{~g} /$ day obtained much of their energy from the protein diet: about $80 \%$ of their total energy was obtained from casein, whereas only $62 \%$ was obtained from casein in rats restricted to $5 \mathrm{~g} /$ day. Body weight gain of rats with lesions decreased in the following order of restriction level and protein source: $5 \mathrm{~g}$ wheat gluten $>5 \mathrm{~g}$ casein $>2 \mathrm{~g}$ casein (Fig. 3). Rats with lesions given wheat gluten gained significantly $(p<0.01)$ more weight than controls without significant increase in total energy intake.

\section{DISCUSSION}

In this work we confirmed the report of Anderson et al.(9) of the first experiments on self-selection regimens that both hypothalamic hyperphagic rats and intact ones can regulate their protein intake and that their hyperphagia is a behavioral error in regulation of energy intake. Self-selecting rats with VMH lesions consumed more food than controls and ate as much as rats on fixed-ratio diet.

Furthermore, the present results of carcass analyses demonstrated normal nitrogen retention with increased body fat in self-selecting rats with VMH lesions. Radcliffe and Webster (18) observed normal protein deposition in obese Zucker rats and suggested that regulation of food intake was linked with body protein maintenance even in Zucker obese rats. Our results on self-selecting rats with VMH lesions support their suggestion. Protein metabolism in rats with VMH lesions has 
been investigated in detail by Holm and coworkers. From studies using nitrogen balance and carcass analyses, they suggested that increased urinary nitrogen excretion was due to impaired amino acid utilization(19), and concluded that hypothalamic hyperphagia was a means to counteract increased amino acid catabolism $(20)$. The unchanged protein intake observed in self-selecting rats with VMH lesions in Experiment 1, however, cannot be explained by the conclusion of Holm et al. Because increased energy consumption will diminish the protein requirement of the body by a protein-sparing effect (10), rats with $\mathrm{VMH}$ lesions may not necessarily consume more protein for maintenance of body protein, even though amino acid catabolism is increased by VMH lesions.

We previously demonstrated that the net dietary protein calories $\%$ (NDpCals $\%$ ) were constant in self-selecting rats regardless of the protein quality, being about $8.5 \%$ in adult rats $(8)$. The values for NDpCals $\%$ of casein obtained from control rats on both fixed-ratio diet and dietary self-selection groups in the present study were identical with our previous results (8). Moreover, we observed a lower NDpCals $\%(5.5-6.1 \%)$ in rats with VMH lesions than in controls regardless of the feeding method and protein source.

In an experiment on dietary protein restriction, rats consumed significantly $(p<0.01)$ less energy on wheat gluten restriction than on casein restriction at the same $\mathrm{N}$ level ( $200 \mathrm{mg} \mathrm{N} /$ day). On the other hand, on non-protein energy restriction $(5 \mathrm{~g} /$ day of protein-free diet), the protein source did not affect total energy consumption. Therefore, energy intake seems to be affected by the amount of dietary protein available for body protein synthesis. Thus, protein-restricted animals could not consume sufficient energy and lost weight. In contrast, restriction of non-protein energy resulted in adaptive increase in consumption of protein as an energy source. Animals with non-protein energy restriction gained more weight than those with protein restriction when consuming the same amount of total energy (Figs. 2 and 3).

Although rats with VMH lesions consumed more energy than controls fed ad libitum, their food intake tended to be reduced more than that of controls in response to dietary protein or non-protein energy restriction. This means that our rats with VMH lesions showed an exaggerated response to an unbalanced ratio of protein to energy in the diet. This response may be regarded as a finickiness resulting from $\mathrm{VMH}$ destruction: $\mathrm{VMH}$ rats are known to show more alteration in food consumption than intact ones in response to the taste of the diet $(21,22)$. The diets used in the self-selection regimen (e.g. $5 \%$ and $70 \%$ protein diets) differed in sweetness from $20 \%$ casein diet because of their difference in sugar content, but the total energy consumption of self-selecting rats did not differ from that of rats given $20 \%$ casein diet. Moreover, although the protein-free diet was the sweetest used in this study, its consumption was less in animals with VMH lesions than in controls when protein intake was restricted. Thus, the taste of the diet did not seem to affect the food intake in the present study. Rats with VMH lesions adapted to selfselection regimen, consuming a constant amount of protein and greater amount of

Vol. 29, No. 2, 1983 
non-protein energy. However, they could not adapt to dietary restriction. Corbit and Stellar (23) found that food intake of animals with VMH lesions was influenced more than in that of intact animals by the texture of the food. In their study, animals with VMH lesions showed little or no hyperphagia when given powdered diet, but displayed definite hyperphagia when switched to the same diet in pellet form. Rats with $\mathrm{VMH}$ lesions with restriction of protein or non-protein energy showed greater reduction of food intake than controls, although they were given paste diets obtained by adding water to the diet.

Though the present study did not provide information on the mechanism underlying regulation of protein intake, animals with or without VMH lesions consumed enough protein to maintain a normal body protein content when kept on a self-selection regimen and fed ad libitum. However, rats with lesions showed an increased response reactivity to an inappropriate ratio of protein to energy in the diet by decrease in food intake. Protein intake, therefore, cannot be explained by the classical hypothesis of dual centers in the ventromedial hypothalamus and the lateral hypothalamus, but may be integrated by other neural networks including the prepyriform cortex (24) and the amygdala (25). Thus further studies are necessary on the regulation of protein intake in relation to whole body protein synthesis in animals with lesions other than in the $\mathrm{VMH}$ as well as in intact animals.

This work was supported in part by a grant (No. 377073) from the Ministry of Education, Science and Culture of Japan.

\section{REFERENCES}

1) Bray, G. A., and York, D. A. (1979): Hypothalamic and genetic obesity in experimental animals: An autonomic and endocrine hypothesis. Physiol. Rev., 59, 719-809.

2) Brobeck, J. R., and Anand, B. K. (1951): Hypothalamic control of food intake in rats and cats. Yale J. Biol. Med., 24, 123-139.

3) Scharrer, E., Baile, C. A., and Mayer, J. (1970): Effect of amino acids and protein on food intake of hyperphagic and recovered aphagic rats. Am. J. Physiol., 400-404.

4) Leung, P. M. B., and Rogers, Q. R. (1970): Effect of amino acid imbalance and deficiency on food intake of rats with hypothalamic lesions. Nutr. Rep. Int., 1, 1-10.

5) Krauss, R. M., and Mayer, J. (1965): Influence of protein and amino acids on food intake in the rat. Am. J. Physiol., 209, 479-483.

6) Rozin, P. (1968): Are carbohydrate and protein intakes separately regulated? J. Comp. Physiol. Psychol., 65, 23-29.

7) Musten, B., Peace, D., and Anderson, G. H. (1974): Food intake regulation in the weanling rat: Self-selection of protein and energy. J. Nutr., 104, 563-572.

8) Kishi, K., Rikimaru, K., Matsumoto, Y., Shizuka, F., and Inoue, G. (1982): Constancy of net protein intake in rats on self-selection regimen with proteins of various qualities. Jpn. J. Physiol., 32, 959-970.

9) Anderson, G. H., Leprohon, C., Chambers, J. W., and Coscina, D. V. (1979): Intact regulation of protein intake during the development of hypothalamic or genetic obesity in rats. Physiol. Behav., 23, 751-755.

10) Munro, H. N. (1964): General aspects of the regulation of protein metabolism by diet 
and hormones, in Mammalian Protein Metabolism, Vol. 1, ed. by Munro, H. N., and Allison, J. B., Academic Press, New York, pp. 381-481.

11) Mayer, J. H., and Hargus, W. A. (1959): Factors influencing food intake of rats fed lowprotein rations. Am. J. Physiol., 197, 1350-1352.

12) MacKay, E. M., Barnes, R. H., and Carne, H. O. (1941): The influence of a diet with a high protein content upon the appetite and deposition of fat'. Am. J. Physiol., 135, 193201.

13) National Institute of Resources, Sciences and Technology Agency (1963): Japanese Food Tables, 3rd ed., Printing office, Finance Ministry.

14) De Groot, J. (1963): The rat forebrain in stereotaxic coordinates. Noord-Hollandsche Uitgevers-Mij, Amsterdam.

15) Lee, M. O. (1929): Determination of the surface area of the white rat with its application to the expression of metabolic results. Am. J. Physiol., 89, 24-33.

16) Miller, D. S., and Bender, A. E. (1955): The determination of the net utilization of protein by a shortened method. Br. J. Nutr., 9, 382-388.

17) Miller, D. S., and Payne, P. R. (1961): Problems in the prediction of protein values of diets: Caloric restriction. J. Nutr., 75, 225-230.

18) Radcliffe, J. D., and Webster, A. J. F. (1976): Regulation of food intake during growth in fatty and lean female Zucker rats given diets of different protein content. Br. J. Nutr., 36, 457-469.

19) Holm, H., Hustvedt, B. E., and Lovo, A. (1973): Protein metabolism in rats with ventromedial hypothalamic lesions. Metabolism, 22, 1377-1387.

20) Holm, H., Lovo, A., and Hustvedt, B. E. (1978): Protein depletion and energy retention in rats with ventromedial hypothalamic lesions. Nutr. Metabol., 22, 22-31.

21) Teitelbaum, P. (1955): Sensory control of hypothalamic hyperphagia. J. Comp. Physiol. Psychol., 48, 156-163.

22) Graff, H., and Stellar, E. (1962): Hyperphagia, obesity, and finickiness. J. Comp. Physiol. Psychol., 55, 418-424.

23) Corbit, J. D., and Stellar, E. (1964): Palatability, food intake, and obesity in normal and hyperphagic rats. J. Comp. Physiol. Psychol., 58, 63-67.

24) Leung, P. M. B., and Rogers, Q. R. (1971): Importance of prepyriform cortex in foodintake response of rats to amino acids. Am. J. Physiol., 221, 929-935.

25) Leung, P. M. B., and Rogers, Q. R. (1973): Effect of amygdaloid lesions on dietary intake of disproportionate amounts of amino acids. Physiol. Behav., 11, 221-226. 